\title{
An Analysis of Financial Report on Profitability of Financial Institutions In Indonesia Stock Exchange
}

Slamet Santosa

Collage of Economics Swasta Mandiri, Indonesia Corresponding email: slamets6873@gmail.com

\begin{abstract}
:
This research was conducted to determine the effect of liquidity, NPL, and capital structure on the profitability of banking financial institutions on the Indonesia Stock Exchange partially and simultaneously. The research method uses a quantitative approach. Data analysis techniques used in this study were multiple regression analysis techniques. Testing research data using the classic assumption test, normality test, multicollinearity test, heteroscedasticity test, and autocorrelation test. The results showed that 1) Liquidity variables have an influence on bank profitability. This causes the customer to trust the bank in providing credit services due to the bank's ability to refinance its obligations to customers who hold their funds using current assets that are running well. 2) The NPL variable has no influence on bank profitability. This causes the amount of problem loans to be greater, causing problems, namely losses caused by the rate of return on bad loans. 3) Variable capital structure has no influence on bank profitability. This is because bank capital is not channeled to the public, thus making the capital unproductive and not producing profits for the company. 4) Simultaneously changes in liquidity, NPL and capital structure variables together have a significant effect on the profitability of banks on the Indonesia Stock Exchange.
\end{abstract}

\section{Keywords:}

liquidity, NPL, capital structure, profitability

JEL: B26, E40, E44

\section{INTRODUCTION}

The main activity of banking financial institutions is to collect funds from the public and channel these funds back to the community and provide other bank services (Kasmir, 2000). From this understanding it can be interpreted that the function and task of banks is to collect and channel funds back to the community in the form of loans or lending to the public. Banks in investing provide facilities in payments and the smooth transfer of goods and services can stimulate economic growth. The diverse nature of the bank's exposure to the bank's liquidity risk is the risk that the bank may not be able to meet its obligations (Jenkinson, 2008), depositors can withdraw funds at any time so that it can cause massive sales of assets (Diamond and Rajan, 2001), negatively affect profitability (Chaplin et al. 2000).

Increasing business competition requires banks to improve their performance in order to attract funds from investors. In investing funds, investors need information about the company's performance. Users of bank financial statements need information that is understandable, relevant, reliable and comparable in evaluating the financial position and performance of banks and useful in making economic decisions (Tweedie \& Seidenstein, 2004). Banking companies that have gone public see the problem of profitability as more important than the problem of profits generated because large profits are not a measure that the company can work efficiently. Efficient can be known by comparing the profits obtained with total assets or often called profitability. According to Ambarwati, Yuniarta \& Sinarwati, 2015), profitability or profitability shows the company's ability to generate profits for a certain period. 
Profitability illustrates the success and ability of a company to use its assets productively, thus the company's profitability can be determined by comparing the profits earned in a period with the amount of assets (return on assets) or the amount of capital the company (return on equity). According to Dendawijaya (2005) an analysis of the profitability ratios of a bank can be measured using Return On Assets (ROA), Return On Equity (ROE), operating cost ratio (BOPO) and Net Profit Margin (NPM). Bank Indonesia, as the supervisor and supervisor of the banking sector, prioritizes the profitability of a bank as measured by assets (Return On Assets / ROA) whose funds are mostly derived from public deposits.

Basically, these ratios can be used to measure the magnitude of financial performance in the banking industry, but the level of profitability of banking companies is usually measured using the financial ratio of Return On Assets (ROA) because ROA is more focused on the company's ability to obtain earnings in overall company operations. In order to obtain the level of profitability as expected, banks are required to optimally manage the assets under control. Problems in banks that often arise in managing assets are solving conflicts between liquidity and security on the one hand with the ability to increase profits on the other. With the management of assets and bank loans intended to minimize the risks that generally consist of operational risk, and risk of human factors (Tho'in, 2019); (Nasih, 2010). In a variety of functions held by a bank exposes them to liquidity risk, liquidity risk has a negative influence on bank profitability. The high economic and banking crisis throughout the world resulted in banks having to have fairly strict regulations regarding liquidity management. Liquidity risk not only affects the bank's performance but also the bank's reputation. The public will assess how well the performance provided by the bank (Authors/Task Force Members, 2014).

With the increasingly complex banking activities resulting in the emergence of NonPerforming Loans (NPL) that are increasingly large. If a bank's operations get bigger it can have an impact on the supervisory aspect which decreases so that the NPL or credit risk is greater. The development of banking today is very tight between banks fighting over the market by giving the best offer of the advantages or advantages of banks. Thus banks can increase credit and reduce NPLs have won half the competition, especially if it has managed to make a profit and maintain Capital Adequacy Ratio (CAR) (Mawardi, 2005).

The liquidity ratio measures the ability of short-term liquidity by looking at current assets against its current debt (Suyanto \& Supramono, 2012). A bank is said to be liquid if the relevant bank can fulfill its debt obligations, can repay all of its deposits, and can fulfill the loan request submitted without delay. Therefore, a bank can be said to be liquid if: (a) the bank has cash assets in the amount of needs used to meet its liquidity, (b) the bank has cash assets that are smaller than its liquidity needs, but has assets or other assets (eg securities ) that can be disbursed at any time without decreasing its market value, and (c) the Bank has the ability to create new cash assets through various forms of debt. A low ratio indicates a high liquidity risk, while a high ratio indicates an excess of current assets, which will have an adverse effect on the company's profitability.

In liquidity ratios, ratios that can be measured include: quick ratio, banking ratio, and loans to assets ratio.

a. Quick Ratio is this ratio to determine the ability to refinance its obligations to customers who save their funds with more liquid assets that are more liquid.

b. Banking Ratio / Loan to Deposit Ratio (LDR), this ratio is to determine the ability of banks to repay obligations to customers who have invested funds with loans that have been given to their debtors. The higher the ratio, the higher the level of liquidity.

c. Loan to Assets Ratio, this ratio is to measure the ability of banks to meet the demands of debtors with available bank assets. The higher the ratio, the lower the level of liquidity. 
Non Performing Loan (NPL) is the non-return of credit on time according to the loan agreement or non-performing loans. Non-performing loans are always in the activities of bank lending, therefore every bank tries to reduce the minimum amount of non-performing loans so as not to exceed the provisions of Bank Indonesia as a banking supervisor. Nonperforming loans are the total amount of substandard loans, plus doubt loans, and bad loans (Harahap, 2003). The NPL ratio is one of the key indicators to assess the performance of bank functions which is then used to assess credit growth at a bank, because the high NPL ratio is an indicator of banks failing in managing a business, such as liquidity problems (inability to pay third parties), Rentability (money cannot be collected), Solvency (reduced capital), while declining profit is one of the consequences because the bank practically loses sources of income in addition to having to set aside reserves according to credit collectibility (Dwihandayani, 2018).

According to Bank Indonesia Regulation No.13/3/PBI/2011 that for commercial banks' NPL ratios have been set at $5 \%$. If the bank is able to reduce the NPL ratio below $5 \%$, the potential for profit will be even greater because the bank will save money that will be needed to form a reserve for non-performing loans or Allowance for Earning Asset Losses (PPAP). With the smaller PPAP that must be formed by banks, the operating profit obtained will be even greater so that the bank's overall performance will improve. Fund management carried out by banks is not only in the form of lending to the public, but can also be used for investment or investment into other earning assets, namely securities such as bonds and Bank Indonesia Certificates (SBI) in the context of strengthening bank liquidity, participation in other business entities and placement as liquid instruments. Loan to Deposit Ratio (LDR) is a ratio used 5 to assess the liquidity of a bank by dividing the amount of credit given by banks to third party funds. The higher this ratio, the lower the liquidity ability of the bank concerned so that the possibility of a bank in problematic conditions will be even greater.

Capital (capital) is one aspect in the assessment of the soundness of a bank or known as CAMEL analysis (Capital, Assets, Management, Earning and Liquidity) (Titman \& Wessels, 1988). In this aspect, it is assessed that capital is owned by banks based on the bank's minimum capital requirement. The assessment is based on CAR (Capital Adequacy Ratio) which has been determined by Bank Indonesia. Merkusiwati (2007) defines capital as a very important factor in the context of business development and to accommodate the risk of loss. Capital also functions to finance operations, as an instrument to anticipate ratios, and as a tool for business expansion. Research on the capital aspects of a bank is intended to find out how or whether the bank's capital is sufficient to support needs. This means that the capital owned by the bank is based on the bank's minimum capital requirement. Dendawijaya (2005) defines the Capital Adequacy Ratio (CAR) is a ratio that shows how far all bank assets that contain risk (credit, inclusion, securities, bills at other banks) are also funded from the bank's own capital funds, in addition to obtaining funds from sources outside the bank such as public funds, loans (debt) and others. In other words, the Capital Adequacy Ratio (CAR) is the ratio of bank performance to measure the adequacy of capital owned by banks to support assets that contain or generate risk, for example loans granted. In addition, CAR is an indicator of a bank's ability to cover a decline in assets as a result of bank losses caused by risky assets. According to Dendawijaya (2005) Indonesian banks require each commercial bank to provide a minimum capital of $8 \%$ of the total Risk Weighted Assets (ATMR).

The CAR ratio assessment based on Bank Indonesia Circular No. 6/23/DPNP dated May 31,2004 is a CAR whose value ranges from $8 \%$ to $9 \%$. According to the Bank for International Settlements (BIS) requires each commercial bank to provide a minimum capital 
of $8 \%$. Bank Indonesia stipulations also regulate the method of calculating risk-weighted assets, which consists of the sum of RWA calculated based on the value of each asset item on the bank's balance sheet multiplied by the respective weighting.

The steps in calculating the minimum capital stock of a bank are as follows (Dendawijaya, 2005): (a) RWA of balance sheet assets is calculated by multiplying the nominal value of each asset concerned by the risk weight of each of these balance sheet posaktiva. (b) RWA of administrative assets is calculated by multiplying the nominal value of the administrative account concerned by the risk weight of each account post. (c) Total RWA = RWA of balance sheet assets + RWA of administrative assets. (d) Bank ratios are calculated by comparing bank capital (core capital + supplementary capital) and ATMR capital.

Bank capital established and headquartered in Indonesia is divided into two (Dendawijaya, 2005), namely: The core capital component consists principally of paid up capital and reserves formed from profit after tax, with the following details: (a) Paid up capital is capital that has been effectively deposited by the owner. (b) Agio share is the excess of capital injection received by a bank as a result of a share price that exceeds its face value. (c) General reserves are reserves that are formed from the allowance for land titles or net income after tax deduction and approval of the general meeting of shareholders or members' meeting in accordance with their respective articles of association. (d) Reserves of destination are the share of profits after deducting the tax set aside for certain purposes and after obtaining approval of the general meeting of shareholders or member meetings. (e) Retained earnings are net income after deducting taxes which are generally held by shareholders or a member meeting decided not to be shared. (f) Last year's earnings are net profits of previous years after tax deduction and their use has not been determined by general meeting of shareholders or meeting of members. Last year's profit calculated as core capital was only $50 \%$. If the bank has a loss balance in the past years, all of the losses will be a deduction from core capital. (g) Current year profit is profit earned in the current financial year after deducting the estimated tax debt. The amount of profit for the current year which is calculated as core capital is only $50 \%$. If a bank experiences a loss in the current year, all of the losses will be a deduction factor from core capital. (h) Portion of the net assets of a subsidiary whose consolidated financial statements are part of the net assets of the subsidiary's core capital after compensation of the value of bank investment in the subsidiary. What is meant by a subsidiary is a non-bank financial institution (LKBB), the majority of whose shares are owned by banks.

Banking Profitability is a capability or ability of banks to make a profit. The problem of profitability or income for banks is an important issue because bank revenue is the main target that must be achieved because the bank was established to get profit. This profit is the main key to support the continuity and development of the bank concerned (Nuryanto, et.al, 2014); (Lin, 2007); (Singh \& Pandey, 2008). Profit obtained from the credit activity in the form of the difference between the cost of funds with interest income received from debtors. Profit is the main goal of a bank so it must be really considered seriously. The size of profitability is more important than the size of income or profit because actually although the company gets a large profit, the company does not necessarily show effective and efficient work performance. In this study the authors measure the profitability of banks using the ratio of Return On Assets (ROA), which is the ratio of Net incom After Tax to assets as a whole shows the size of asset productivity in providing returns on investment (Sawir, 2001).

Return on Assets (ROA) is a ratio used to measure the ability of bank management to obtain overall benefits. The greater the bank ROA, the greater the level of profit achieved by the bank and the better the bank's position and the use of assets. 


\section{Hypothesis}

H1: Liquidity has a significant influence on changes in banking profitability;

H2: Non Performing Loans (NPL) have a significant influence on changes in bank profitability.

H3: Capital structure has a significant influence on changes in bank profitability.

H4: Simultaneously, liquidity, NPL, and capital structure have a significant influence on changes in bank profitability.

\section{RESEARCH METHODS}

The approach used in this study is a quantitative approach, namely analyzing the measurement of economic phenomena which is a combination of economic theory (financial statement information), mathematical models and statistics classified in certain categories using certain tables in order to facilitate the analysis using the SPSS program 22.0 for windows. While the analysis technique used is multiple regression analysis techniques to see or predict the state (ups and downs) of the dependent variable (criterium), if two or more independent variables as predictor factors are manipulated (raised the value down) so multiple regression analysis will be carried out by the number five (5) independent variable (Sugiyono, 2012).

Testing data uses (a) Classical Assumption Test, where the classic assumption test is used to test whether the regression model really shows a significant and representative relationship. There are four tests in the classical assumption test. (b) Normality test, the normality test aims to test whether in the regression model the independent variable and the dependent variable or both are normally distributed or not. A good regression model is having normal data distribution. To detect normality can be tested with Kolmogoraf-Smirnof. (c) Multicollinearity Test, this test aims to test whether in the regression model found a high or perfect correlation between independent variables or not. The way to detect it is if multicollinearity is high, it is likely that a high $\mathrm{R}^{2}$ is obtained but none or very few coefficients are estimated to be statistically significant. A good model should not have a high correlation between independent variables. The intercorrelation can be seen by the value of the correlation coefficient between the independent variables, the value of the Variance Inflation Factor (VIF) and Tolerance, the Eigenvalue and Condition Index values, and the standard error value of the beta coefficient or partial regression coefficient. (d) Heteroscedasticity test, this test aims to test whether in the regression model there is an inequality of variance and residuals from one observation to another. If the variance and residuals of one observation to another are fixed, then it is called homoscedasticity, and if the variance from the residuals of one observation to another observation is called heteroscedasticity. To detect the presence or absence of heteroscedasticity can be done by looking at scatterplot charts, on the basis of analysis (Ghozali, 2006). (e) Autocorrelation Test, the aim is to test whether in a multiple linear regression model there is a correlation between residuals in period $t$ and residuals period t-1 (previous). A good regression model is free from autocorrelation. To detect the presence or absence of autocorrelation, a Durbin-Watson (DW) test is performed with the following conditions (Sulaiman, 2004). (1) $1.19<\mathrm{DW}<1.73$ Means correlation does not occur (2) $1.19<\mathrm{DW}<1.79<\mathrm{DW}<.79$ Means that is not concluded (3) DW $<1.19$ or 2.79 Means correlation occurs 


\section{RESULTS AND DISCUSSION}

$\mathrm{H}_{1}$ test results show that liquidity (quick ratio) affects the profitability (return on assets) of banks. Viewed from the significant value of liquidity of 0.024 where $0.024<0.05$. Thus $\mathrm{H}_{1}$ is partially rejected, meaning to measure the level of profitability of the QR variable banks into benchmarks for the bank to obtain high profits. This research is supported by Wahyudi, et.al (2013) which states that liquidity has a positive effect on bank profitability. The ability of banks to refinance their obligations to customers who hold their funds using current assets that affect the level of bank profitability. The higher QR level causes an increase in ROA.

$\mathrm{H}_{2}$ test results show that NPL has no significant effect on bank profitability (return on assets). Judging from the significant NPL value of 0.106 where $0.106>0.05$ and the value of $t$ is between -2.018 and 2.018. Thus $\mathrm{H}_{2}$ is partially rejected, meaning that the higher this ratio will affect the quality of bank credit which causes the amount of problem loans is greater then the possibility of a bank in a problematic condition that is a loss caused by the rate of return on bad loans. This research is supported by Wahyudi, et.al (2013) which states that NPL has no effect on bank profitability. The existence of high NPL will create difficulties and reduce the soundness of the bank concerned. The increase in NPL resulted in banks having to provide reserves for write offs that were large enough so that the ability to provide credit was very limited. A high NPL will not cause a decrease in ROA or vice versa.

$\mathrm{H}_{3}$ test results show that CAR has no significant effect on bank profitability (return on assets). Judging from the significant CAR value of 0.093 where $0.106>0.05$ and the tcount is between -1.018 and 2.018. Thus partially rejected $\mathrm{H}_{3}$, meaning that the capital structure does not become a benchmark in obtaining high profits. This research is supported by Rini Wigiyawati (2011) which states that capital structure has no effect on bank profitability. A high CAR ratio does not cause an increase in ROA. Bank capital is not channeled to the public making the capital unproductive and does not generate profits for the company. Banking capital is more widely used to expand the banking service network by opening new offices so that the number of commercial bank offices continues to increase.

$\mathrm{H}_{4}$ test results show that Liquidity (QR), NPL and Capital Structure (CAR) have an influence on banking profitability. Thus, $\mathrm{H}_{4}$ is simultaneously accepted, meaning that $\mathrm{QR}$, NPL and CAR affect bank profitability.

\section{CONCLUSION}

The results showed that 1) Liquidity variables have an influence on bank profitability. This causes the customer to trust the bank in providing credit services due to the bank's ability to refinance its obligations to customers who hold their funds using current assets that are running well. 2) The NPL variable has no influence on bank profitability. This causes the amount of problem loans to be greater, causing problems, namely losses caused by the rate of return on bad loans. 3) Variable capital structure has no influence on bank profitability. This is because bank capital is not channeled to the public, thus making the capital unproductive and not producing profits for the company. 4) Simultaneously changes in liquidity, NPL and capital structure variables together have a significant effect on the profitability of banks on the Indonesia Stock Exchange.

\section{REFERENCES}

Ambarwati, N. S., Yuniarta, G. A., AK, S., \& Sinarwati, N. K. (2015). Pengaruh modal kerja, likuiditas, aktivitas dan ukuran perusahaan terhadap profitabilitas pada perusahaan manufaktur yang terdaftar di bursa efek Indonesia. JIMAT (Jurnal IImiah Mahasiswa Akuntansi) Undiksha, 3(1). 
Authors/Task Force Members, Kristensen, S. D., Knuuti, J., Saraste, A., Anker, S., Bøtker, H. E., ... \& Heyndrickx, G. R. (2014). 2014 ESC/ESA Guidelines on non-cardiac surgery: cardiovascular assessment and management: The Joint Task Force on non-cardiac surgery: cardiovascular assessment and management of the European Society of Cardiology (ESC) and the European Society of Anaesthesiology (ESA). European heart journal, 35(35), 2383-2431.

Chaplin, G., Emblow, A., \& Michael, I. (2000). Banking system liquidity: developments and issues. Financial Stability Review, 4, 93-112.

Dendawijaya, L. (2005). Manajemen perbankan.

Diamond, D. W., \& Rajan, R. G. (2001). Liquidity risk, liquidity creation, and financial fragility: A theory of banking. Journal of political Economy, 109(2), 287-327.

Dwihandayani. (2018). Analisis Kinerja Non Performing Loan (Npl) Perbankan di Indonesia dan Faktor-faktor yang Mempengaruhi Npl. Jurnal Ilmiah Ekonomi Bisnis, 22(3).

Harahap, M. J. Analisis Non Performing Loan (Npl) Pada PT. Bank Sumut Capem Sei Rampah.

Kasmir, S. (2000). From the margins: Punk rock and the repositioning of ethnicity and gender in Basque identity. Basque Cultural Studies, University of Nevada, Reno, 178-204.

Lin, B. W. (2007). Information technology capability and value creation: Evidence from the US banking industry. Technology in Society, 29(1), 93-106.

Mawardi, N. (2005). Faktor-faktor yang mempengaruhi penetapan return bagi hasil deposito mudharabah muthlaqah: studi kasus pada unit syariah bank $x$ (Doctoral dissertation).

Merkusiwati, N. K. L. A. (2007). Evaluasi pengaruh CAMEL terhadap kinerja perusahaan. Buletin Studi Ekonomi, 12(1), 100-108.

Nasih, M. (2010). Intellectual Capital dan Kinerja Perusahaan Perbankan di Indonesia. Journal of Economics and Business Airlangga, 20(2).

Nuryanto, R., Tho'in, M., \& Wardani, H. K. (2014). Rasio Likuiditas, Rasio Solvabilitas, Rasio Rentabilitas Koperasi Jasa Keuangan Syariah Di Jawa Tengah. Jurnal Akuntansi dan Pajak, 15(01).

Sawir, A. (2001). Analysis of financial performance and corporate financial planning. Jakarta: PT Gramedia Pustaka Utama.

Singh, J. P., \& Pandey, S. (2008). Impact of Working Capital Management in the Profitability of Hindalco Industries Limited. ICFAl journal of financial Economics, 6(4).

Suyanto, K. D., \& Supramono, S. (2012). Likuiditas, Leverage, Komisaris Independen, dan Manajemen Laba terhadap Agresivitas Pajak Perusahaan. Jurnal Keuangan dan Perbankan, 16(2).

Tho'in, M. (2017). Analysis Of Islamic Bank Customer's Satisfaction Using Importance Performance Analysis (IPA). ADRI International Journal Of Marketing and Entrepreneurship, 1(1), 42-48.

Tho'in, M. (2019). The Comparison of Islamic Banking Financial Performance In Indonesia. International Journal of Scientific Research And Education, 7(5).

Titman, S., \& Wessels, R. (1988). The determinants of capital structure choice. The Journal of finance, $43(1), 1-19$.

Tweedie, D., \& Seidenstein, T. R. (2004). Setting a global standard: The case for accounting convergence. Nw. J. Int'l L. \& Bus., 25, 589.

Wahyudi, I., Dewi, M. K., Rosmanita, F., Prasetyo, M. B., Putri, N. I. S., \& Haidir, B. M. (2013). Manajemen Risiko Bank Islam. Jakarta: Salemba Empat. 